1046

\section{BRONCHOPULMONARY DYSPLASIA: AN UPDATE ON NUTRITIONAL ISSUES}

\section{Bozzetti}

NICU, Ospedale San Gerardo Monza, Monza, Italy

The continuous advances in the intensive care of preterm newborns have led to a progressive decline of mortality. However, the success in the survival achieved through an aggressive intensive care is not always paralleled by a subsequent fully healthy development of the newborn.

Bronchopulmonary dysplasia (BPD) is one of the conditions of morbidity due to the prematurity. Nutrition plays a critical role in the prevention and management of BPD. Malnutrition can worsen BPD by compromising lung growth: early postnatal nutritional deprivation causes a decrease of cell number due to suboptimal cell division. Moreover, drugs used in BPD therapy (corticosteroids, diuretics...) can have adverse effects on growth. This review focuses on the recommended nutritional intakes during the acute and chronic phase of the illness. Adequate intakes, and in the right timing, of fluid, parenteral nutrition with glucose, protein and lipids in the correct proportions, vitamin $A$ supplementation and early enteral feeding may help decrease the incidence of BPD and may reduce its severity. A close monitoring of the biochemical nutritional indexes is also necessary to achieve adequate growth and to avoid nutritional deficiencies.

A careful post-discharge follow-up of these infants is necessary since the $67 \%$ of infants with BPD continue to have growth retardation after hospital discharge due to difficulties in ensuring adequate intakes (feeding difficulties, increased metabolic demands..).

We present our guidelines on recommended nutritional intakes after a careful review of all the scientific literature.

\begin{tabular}{|l|l|l|l|}
\hline & $\begin{array}{l}\text { TRANSI- } \\
\text { TIONAL } \\
\text { PERIOD }\end{array}$ & $\begin{array}{l}\text { TRANSI- } \\
\text { TIONAL } \\
\text { PERIOD }\end{array}$ & $\begin{array}{l}\text { MAINTE- } \\
\text { NANCE } \\
\text { PERIOD }\end{array}$ \\
\hline & INITIATION & INCREMENTS & $110-150$ \\
\hline $\begin{array}{l}\text { Fluids }(\mathrm{mL} / \\
\text { Kg/day) }\end{array}$ & $70-100$ & $10-20$ & $110-130$ \\
\hline $\begin{array}{l}\text { Calories } \\
\text { (Kcal/Kg/ } \\
\text { day) }\end{array}$ & $40-60$ & $10-15$ & $10-12$ \\
\hline $\begin{array}{l}\text { Carbohy- } \\
\text { drate }(\mathrm{mg} / \\
\text { kg/min) }\end{array}$ & $4-6$ & 1 & 4 \\
\hline $\begin{array}{l}\text { Protein }(\mathrm{g} / \\
\text { Kg/day) }\end{array}$ & 3 & $0.5-1$ & 3 \\
\hline $\begin{array}{l}\text { Lipid (g/Kg/ } \\
\text { day) }\end{array}$ & $0.5-1$ & $0.5-1$ & 3 \\
\hline $\begin{array}{l}\text { Sodium } \\
\text { (mEq/Kg/ } \\
\text { day) }\end{array}$ & minimal & 2 & \\
\hline
\end{tabular}

[Recommendations for parenteral nutrition]

\section{7}

\section{CONGENITAL ANALBUMINEMIA: A SASKATCHEWAN CASE SERIES}

\author{
J.M. Toye ${ }^{1}$, K. Baerg' ${ }^{2}$, E.G. Lemire ${ }^{3}$ \\ ${ }^{1}$ University of Saskatchewan, ${ }^{2}$ Paediatrics, \\ ${ }^{3}$ Genetics, University of Saskatchewan, \\ Saskatoon, SK, Canada
}

Background: Congenital analbuminemia (CAA) is characterized by the absence of serum albumin. Typically albumin is the most abundant protein in the circulatory system and provides $80 \%$ of the colloid osmotic pressure. Albumin is responsible for carrying many molecules through the circulation. Therefore it unexpected that survival without albumin is possible. The worldwide prevalence of CAA is estimated at 1 in 1,000,000. There are 43 cases of CAA reported internationally, but there is very little information known about the impact of the absence of albumin. We have identified a population in Saskatchewan with a high incidence of CAA. Our intent is to review these cases and determine whether CAA has an impact on these patient morbidity and/or mortality.

Methods: We identified thirteen cases of CAA from health records. Data collection included antenatal/obstetrical history, birth history, placental pathology, frequency of respiratory tract infections, frequency of hospitalization, complications during hospitalizations, co-morbid conditions, laboratory 